\title{
Effect of Selected Biopesticides in Reducing Soybean Rust (Phakopsora pachyrhizi) Development
}

\author{
M. Twizeyimana ${ }^{1}$ and G. L. Hartman ${ }^{1,2, \dagger}$ \\ ${ }^{1}$ Department of Crop Sciences, University of Illinois Urbana-Champaign, Urbana, IL 61801 \\ ${ }^{2}$ U.S. Department of Agriculture Agricultural Research Service, Urbana, IL 61801
}

\begin{abstract}
The intensive use of fungicides in controlling soybean rust (SBR), a damaging foliar fungal disease of soybean caused by the obligate fungus Phakopsora pachyrhizi, may have accelerated the insensitivity of $P$. pachyrhizi populations to fungicides. The objective of this study was to determine the effect of selected biopesticides and their application time on reducing SBR infection. There were differences $(P<0.05)$ in percent rust reduction values for application times, biopesticide treatments,

reduced $(\alpha=0.05$ ) fungal infection compared with the nonfungicide control. Among the treatments, Bacillus subtilis QST 713 and acibenzolar-S-methyl often reduced fungal sporulation more than the other treatments in detachedleaf and whole-plant greenhouse experiments. The identification of biopesticides effective to $P$. pachyrhizi may be a valuable alternative or complement to synthetic fungicides and may be useful in integrated pest management programs for SBR control.
\end{abstract} and their interaction in detached-leaf and whole-plant greenhouse experiments. All application times and nearly all biopesticide treatments
Keyword: disease management
Soybean rust (SBR; Phakopsora pachyrhizi Syd.) inflicts yield losses to soybean [Glycine max (L.) Merr.] especially in areas where the disease is endemic and there is a lack of effective control measures. Yield losses of up to $80 \%$ in experimental trials in Asia (Hartman et al. 1991), 60\% in Brazil and Paraguay (Yorinori et al. 2005), and up to $27 \%$ in experimental plots and $60 \%$ in a commercial field in the United States (Mueller et al. 2009; Sikora et al. 2014) have been reported.

The management of SBR is achieved primarily through well-timed applications of fungicides (Mueller et al. 2009; Sikora et al. 2014). Fungicides consisting of triazoles, strobilurins, and their mixtures were found to be the most effective way to manage SBR in experimental plots (Mueller et al. 2009; Sikora et al. 2014) and commercial soybean fields in regions of Brazil and the United States (Godoy 2012; Sikora et al. 2014). Despite the efficacy of fungicides to control SBR, the intensive use of fungicides, especially single mode of action fungicides, can result in pathogen-resistant populations, hindering management in consecutive crop seasons (Cook 2001). For instance, some triazole fungicides were reported ineffective in controlling SBR in fields (Godoy 2012). The Fungicide Resistance Action Committee recommends applying fungicides in mixtures to boost their mode of action and applying them preventively or as early as possible in the disease cycle, especially when rust pressure is very high and climatic conditions are conducive for pathogen development.

Current address of M. Twizeyimana: AgBiome Inc., Research Triangle Park, NC 27709.

${ }^{\dagger}$ Corresponding author: G. L. Hartman; ghartman @illinois.edu or glen.hartman@ars.usda.gov

Funding: Mention of trade names or commercial products in this publication is solely for the purpose of providing specific information and does not imply recommendation or endorsement by the U.S. Department of Agriculture. USDA is an equal opportunity provider and employer.

The author(s) declare no conflict of interest.

Accepted for publication 18 April 2019.

This article is in the public domain and not copyrightable. It may be freely reprinted with customary crediting of the source. The American Phytopathological Society, 2019.
Planting resistant cultivars is another option for the management of SBR (Twizeyimana et al. 2008). Although there has been progress in identifying resistance genes against SBR, breeding for resistance has been hampered because $P$. pachyrhizi, an obligate pathogen with potentially high virulence variability, can rapidly overcome the major resistance genes and this has made it difficult to develop cultivars that are universally resistant to P. pachyrhizi (Hartman et al. 2005).

Because of the potential ineffectiveness of most synthetic fungicides and commercial soybean cultivars to combat rust, other management techniques (e.g., adopting cultural practices such as staggering the time of planting; Twizeyimana et al. 2011) including the potential use of biopesticides need to be further investigated and included in integrated pest management (IPM) programs designed for the management of SBR. Biopesticides have been defined narrowly and broadly. Copping and Menn (2000) defined biopesticides as a wide range of different materials and organisms occurring naturally, which generally refer to the following: microbial (bacterial, fungal, and viral) organisms, entomophagous nematodes, plantderived pesticides (botanicals), secondary metabolites from microorganisms (antibiotics), insect pheromones, and genes used to transform crops. Similarly, the U.S. Environmental Protection Agency defines biopesticides as pesticides derived from natural materials such as animals, plants, bacteria, and certain minerals. Biopesticides fall into three major classes: (i) biochemical pesticides, which consist of naturally occurring substances, or synthetically derived equivalents, which mostly include semiochemicals (insect pheromones and kairomones), natural plant and insect regulators, naturally occurring repellents and attractants, induced resistance promoters, and enzymes; (ii) microbial pesticides (microorganisms with pesticidal modes of action that often include competition or inhibition, toxicity, and even use of the target pest as a growth substrate); and (iii) plantincorporated protectants, which consist of pesticidal substances that plants produce when a genetic material has been added to the plant (Leahy et al. 2014).

The control of SBR using biopesticides has not yet been fully explored; however, there have been reports of antagonistic microorganisms to P. pachyrhizi (Saksirirat and Hoppe 1990, 1991a; Ward et al. 2012). The fungus Simplicillium lanosoniveum was reported to colonize soybean leaves infected with $P$. pachyrhizi in Louisiana and Florida; as the uredinia erupted, the fungus began to colonize urediniospores, which led to the death of many urediniospores (Ward et al. 2012). The development of new uredinia was reduced by approximately fourfold when $S$. lanosoniveum colonized uredinia and there 
was reduced disease severity under field conditions. Fungal hyperparasites with mycelium growing on $P$. pachyrhizi urediniospores were isolated and identified as species of Trichothecium, Tuberculina, and Verticillium in Taiwan and Thailand (Saksirirat and Hoppe 1990, 1991a) and Trichothecium roseum in India (Sangit and Jha 2002). Light and scanning electron microscopy showed that the mycoparasite $V$. psalliotae was able to colonize urediniospores of $P$. pachyrhizi. Most spores appeared heavily damaged without any visible mycelium inside and this was caused by the production of lytic enzymes by V. psalliotae (Saksirirat and Hoppe 1991b). Bacillus subtilis (QST-713) and B. pumilus (QST-2808) strains reduced infection caused by $P$. pachyrhizi in detached-leaf, greenhouse, and field experiments (Dorighello et al. 2015). Furthermore, strains of Bacillus and Trichoderma were reported to reduce infection of other rusts; for example, $B$. subtilis strains AP-3 and AP-150 reduced the number of lesions on the detached leaves and whole plant of coffee (Bettiol and Várzea 1992). Trichoderma harzianum strains led to decreases in the number of developing uredial pustules of the bean rust fungus Uromyces appendiculatus in a leaf disk assay (Burmeister and Hau 2009).

Similarly to biocontrol agents, systemic acquired resistance (SAR) inducers and natural products may be used to reduce SBR infection and development. SAR is a form of induced resistance that is activated throughout a plant after being exposed to elicitors from virulent, avirulent, or nonpathogenic microbes or artificial chemical stimuli (Hartman et al. 2016). The compounds acibenzolar-S-methyl, a benzothiadiazole, and harpin protein are known to be SAR inducers in plants against a wide range of plant diseases (Gorlach et al. 1996; Obradovic et al. 2005; Walters et al. 2005; Wei et al. 1992). For rust diseases, acibenzolar-S-methyl had a longer latent period and reduced rust infection on soybean plants (Cruz et al. 2014), whereas harpin protein significantly decreased the incidence of rust (P. zizyphivulgaris) on winter jujube (Ziziphus jujube) by up to $87 \%$ (Li et al. 2012). For natural products, essential oils from Azadirachta indica (neem oil), Corymbia citriodora, and Cymbopogon nardus moderately reduced spore germination in agar plates and infection of $P$. pachyrhizi on plants in greenhouse experiments, as rust severity was reduced by 35 to $62 \%$ compared with the infected control (Medice et al. 2007).

Finding effective biopesticides that can be integrated into IPM programs for the management of SBR may lead to a reduction in the use of synthetic fungicides. The objective of this study was to evaluate the potential of selected biopesticides and their timing of application in reducing fungal sporulation of $P$. pachyrhizi on soybeans.

\section{Materials and Methods}

Plant material and inoculum. Two soybean cultivars, Williams 82 (a universal SBR-susceptible cultivar) and Asgrow 2242 (a commercial SBR-susceptible cultivar), were used in the detached-leaf trials, whereas only Williams 82 was used in the whole-plant trials. Plants were inoculated with isolate FL07-1 collected from Gadsden, Florida, in 2007. The isolate was multiplied on detached leaves of Williams 82 to produce adequate amounts of spores for the experiments. Details on the maintenance and increase in inoculum are described elsewhere (Twizeyimana and Hartman 2010).
Biopesticides used. The biopesticides used included (i) two bioantagonist products, Cease (B. subtilis QST 713) and PlantShield HC (Trichoderma harzianum T-22); (ii) two plant defense activators or SAR inducers, Actigard 50WG (acibenzolar-S-methyl) and Messenger STS (harpin protein); and (iii) a plant extract, Trilogy Neem Oil (Table 1).

Effect of selected biopesticides and timing of their application on fungal sporulation using a detached-leaf assay. Briefly, excised leaflets from plants of Williams 82 and Asgrow 2242 grown in a growth chamber were rinsed in three changes of sterile distilled water and cut into leaf sections (approximately $2 \times 4 \mathrm{~cm}$ each). Leaf sections were placed adaxial side down on $150-\mathrm{mm}$-diameter filter papers (Whatman International Ltd.) in plastic Petri dishes $140 \mathrm{~mm}$ in diameter by $20 \mathrm{~mm}$ deep with sterile filter papers (two per dish) saturated with sterile distilled water (approximately $5 \mathrm{ml} / \mathrm{dish}$ ) (Twizeyimana and Hartman 2010). Their abaxial surface was sprayed with $150 \mu \mathrm{l}$ of Cease (at a dose of $10 \mathrm{ml} /$ liter), PlantShield HC (3.7 g/liter), Actigard 50WG (0.070 g/liter), Messenger STS (0.7 $\mathrm{g} /$ liter), and Trilogy Neem Oil (10 ml/liter) using an atomizer attached to an air compressor $1,3,5$, and 8 days before inoculation; at the start of the experiment (or $3 \mathrm{~h}$ after inoculation); and 1, 3, 5, and 8 days after inoculation. The control was sprayed with water. A spore suspension of isolate FL07-1 $\left(1 \times 10^{5}\right.$ spores $/ \mathrm{ml}$ of sterile distilled water with $0.02 \%$ Tween 20 ) was used as inoculum and sprayed on the abaxial surface of leaf pieces $(150 \mu \mathrm{l}$ for each piece) using an atomizer attached to an air compressor. Dishes with inoculated leaflets were placed inside zip-top bags (Webster Industries) and incubated in the dark for a period of $12 \mathrm{~h}$ followed by a cycle of $14 \mathrm{~h}$ of light $\left(50 \mu \mathrm{mol} / \mathrm{m}^{-2} / \mathrm{s}\right)$ and $10 \mathrm{~h}$ of darkness inside a tissue chamber (Percival Scientific Inc.) maintained at $23^{\circ} \mathrm{C}$.

The experimental design was a split-plot randomized complete block with three replications. The main plot was the timing of treatments (nine times) and the subplot was the treatments used, which included five biopesticides and the controls (inoculated and noninoculated without biocontrol product). The plants were rated 14 days after inoculation by counting the number of sporulating uredinia in an arbitrarily selected $1-\mathrm{cm}^{2}$ area of leaf tissue. The experiment was repeated (trials 1 and 2).

Effect of selected biopesticides and timing of their application on fungal sporulation using whole plants. This experiment was conducted in a biosafety level 2 greenhouse at $22 \pm 2^{\circ} \mathrm{C}$ under a 16-h photoperiod with supplemental illumination provided by 1,000-W Metalarc high-intensity lamps (Sylvania). Seeds of Williams 82 were sown in soil-less mix (Sunshine Mix, LC1; Sun Gro Horticulture Inc.) in 18-cell plastic inserts inside a flat $(52 \times 26 \times$ $6 \mathrm{~cm}$; Hummert International). Plants were fertilized at planting with slow-release pellets (Osmocote 19-6-12; one to two pellets per square centimeter) and thinned to one plant per cell after emergence. The treatments, application times, and experimental design were the same as previously described except there was no day 3 treatment before and after inoculation. Plants were inoculated with a spore suspension of isolate FL07-1 $\left(1 \times 10^{5}\right.$ spores $/ \mathrm{ml}$ of sterile distilled water with $0.02 \%$ Tween 20 ) until runoff using a hand sprayer. The plants were rated 14 days after inoculation by counting the number of sporulating uredinia in an arbitrarily selected $1-\mathrm{cm}^{2}$ leaf tissue of leaflets from an inoculated trifoliate. The experiment was repeated (trials 1 and 2).

Table 1. Biopesticide products used in reducing fungal sporulation of Phakopsora pachyrhizi

\begin{tabular}{llcc}
\hline Commercial name & \multicolumn{1}{c}{ Activity } & Rate (per liter) & Manufacturer \\
\hline Bioantagonists & & $3.7 \mathrm{~g}$ & BioWorks, Inc. \\
$\quad \begin{array}{l}\text { PlantShield HC } \\
\text { Cease }\end{array}$ & $\begin{array}{l}\text { Trichoderma harzianum (T-22) } \\
\text { Bacillus subtilis (QST 713) }\end{array}$ & $10 \mathrm{ml}$ & BioWorks, Inc. \\
$\begin{array}{l}\text { Plant defense activators } \\
\text { Actigard 50WG }\end{array}$ & Acibenzolar-S-methyl (50.0\%) & $0.07 \mathrm{~g}$ & Syngenta Crop Protection \\
$\quad \begin{array}{l}\text { Messenger STS } \\
\text { Plant extract }\end{array} \quad$ Harpin protein (3\%) & $0.7 \mathrm{~g}$ & Eden Bioscience Corp. \\
$\quad$ Trilogy Neem Oil EC & Clarified hydrophobic extract of neem oil (70\%) & $10 \mathrm{ml}$ & Certis USA, LLC \\
\hline
\end{tabular}


Data analyses. The number of sporulating uredinia per each treatment was used to calculate percent control values of sporulating uredinia as follows: $100-[$ (number of sporulating uredinia from each treatment/number of sporulating uredinia from the inoculatednontreated treatment $) \times 100$ ]. Percent control values of sporulating uredinia were transformed using arcsine transformation before analysis.

Analysis of variance (ANOVA) in PROC GLM of SAS (version 9.3; SAS Institute Inc.) was used to test for homogeneity of error variance of data from repeated experiments. Because no heterogeneity was detected, trials were pooled together and tested by ANOVA in SAS. Means of transformed percent disease control values of Asgrow 2242 and Williams 82 in the detached-leaf assays and Williams 82 for the greenhouse test were compared using the Fisher protected least significant difference mean separation test at $\alpha=0.05$. Pearson correlation (PROC CORR) was used to establish the relationship between transformed percent disease control values of Asgrow 2242 and Williams 82 in the detached-leaf assays. A paired-sample $t$ test was conducted to examine whether there were differences between transformed percent disease control values of Asgrow 2242 and Williams 82. In addition, the relationship between transformed percent disease control values recorded only on Williams 82 in the detached-leaf assay and greenhouse test was examined.

\section{Results}

Effect of selected biopesticides and timing of their application on fungal sporulation using a detached-leaf assay. There were differences $(P<0.0001)$ in the reduction of sporulating uredinia for application times, biopesticide and control treatments, and their interaction (Table 2). All application times and biopesticide treatments reduced $(\alpha=0.05)$ sporulating uredinia compared with the inoculated control without biopesticide treatment except for Trichoderma harzianum T-22 applied 6 and 8 days after inoculation for Williams 82 and for neem oil applied 8 days after inoculation for Asgrow 2242 (Fig. 1).

The application time of $3 \mathrm{~h}$ after inoculation had higher percent rust reduction values for $B$. subtilis QST 713 followed by acibenzolarS-methyl, Harpin protein, neem oil, and Trichoderma harzianum T-22 for Williams 82 (93.7, 90.4, 87.4, 84.1, and 74.9\%, respectively) and for Asgrow 2242 (95.7, 86.6, 91.5, 88.4, and 82.5\%, respectively). However, there were no differences in rust reduction for Trichoderma harzianum T-22 applied $3 \mathrm{~h}$ after or 1 day before inoculation for Williams 82 or for all biopesticides applied $3 \mathrm{~h}$ after or 1 day before inoculation and for acibenzolar-S-methyl applied $3 \mathrm{~h}$ after or 1 day after inoculation for Asgrow 2242. For both cultivars, treatments with B. subtilis QST 713 had higher numbers of rust reduction across application times in general and were followed by acibenzolar-Smethyl, whereas Trichoderma harzianum T-22 had lower numbers (Fig. 1). A two-tailed $t$ test showed that biopesticide treatments had significantly higher $(P<0.0001)$ mean transformed percent rust reduction values on Asgrow 2242 than on Williams 82 in the detached-leaf assays.

Table 2. Two-way analysis of variance using transformed percent soybean rust reduction values from the detached-leaf experiments for treatments (biopesticides), application times, trial, block, and interaction between biopesticides and application times ${ }^{\mathrm{x}}$

\begin{tabular}{|c|c|c|c|c|c|}
\hline \multirow[b]{2}{*}{ Source of variation } & \multirow[b]{2}{*}{$d f$} & \multicolumn{2}{|c|}{ Williams 82} & \multicolumn{2}{|c|}{ Asgrow 2242} \\
\hline & & MS & $F$ ratio $^{y}$ & MS & $F$ ratio \\
\hline Treatments ${ }^{\mathrm{z}}$ & 5 & 7.53 & $1291.97 *$ & 8.07 & $629.33^{*}$ \\
\hline Application times & 8 & 1.56 & $268.12^{*}$ & 1.93 & $151.05^{*}$ \\
\hline $\begin{array}{l}\text { Treatments } \times \text { application } \\
\text { times }\end{array}$ & 40 & 0.10 & $16.56^{*}$ & 0.14 & $10.96^{*}$ \\
\hline Trial & 1 & 0.01 & $1.53(\mathrm{~ns})$ & 0.01 & $0.54(\mathrm{~ns})$ \\
\hline Block & 2 & 0.01 & $2.26(\mathrm{~ns})$ & 0.05 & $3.59(\mathrm{~ns})$ \\
\hline
\end{tabular}

$\mathrm{x}$ Percent rust reduction was calculated as follows: [100 - (number of sporulating uredinia per number of sporulating uredinia from the inoculated-nontreated treatment) $\times 100] . d f=$ degrees of freedom, $\mathrm{MS}=$ mean squares, and ns $=$ not significant.

${ }^{y}$ Asterisks indicate that significant differences were found at $P<0.001$.

$\mathrm{z}$ Treatments included five biopesticides and the inoculated control without a biopesticide treatment.
Effect of selected biopesticides and timing of their application on fungal sporulation using whole plants. There were differences $(P<0.0001)$ in the reduction of rust infection for application times, biopesticide and control treatments, and their interaction (Table 3$)$. All application times and biopesticide treatments reduced $(\alpha=$ 0.05 ) fungal sporulation compared with the inoculated control without biopesticide treatment except for Trichoderma harzianum T-22 applied 8 days after inoculation (Fig. 2). The application time of $3 \mathrm{~h}$ after inoculation had higher percent fungal sporulation reduction values (89.6, 85.2, 84.8, 84.3, and 67.1\%) for B. subtilis QST 713, acibenzolar-S-methyl, harpin protein, neem oil, and Trichoderma harzianum $\mathrm{T}-22$, respectively. There were no differences $(\alpha=$ 0.05 ) in fungal sporulation reduction for all biocontrol products applied $3 \mathrm{~h}$ after or 1 day before inoculation except for neem oil; however, there were differences in fungal sporulation reduction when biocontrol products were applied $3 \mathrm{~h}$ or 1 day after inoculation except for acibenzolar-S-methyl. B. subtilis QST 713 had higher numbers of rust reduction across application times in general but they were similar to those of acibenzolar-S-methyl except when the biological product was applied 8 days before inoculation. Trichoderma harzianum T-22 had lower numbers.

Significant positive correlations $(r=0.95, P<0.0001)$ occurred between mean transformed percent disease control values recorded on Williams 82 and Asgrow 2242 in the detached-leaf experiments and in the same cultivars in the detached-leaf and greenhouse experiments on Williams 82 (Table 4).

\section{Discussion}

The B. subtilis QST 713 treatment reduced P. pachyrhizi sporulation to $>90 \%$ of the inoculated control when applied $3 \mathrm{~h}$ after inoculation and in general reduced $P$. pachyrhizi sporulation better than most of the other biopesticide products in the detached-leaf and whole-plant greenhouse experiments. The identification of biopesticides that can effectively control SBR alone or be applied in rotation or mixed with existing synthetic fungicides to provide an alternative mode of action may result in improved IPM programs with less dependence on synthetic fungicides.

The B. subtilis QST 713 strain was reported to have activity against $P$. pachyrhizi (Dorighello et al. 2015) and other fungal pathogens, including Podosphaera spp. (Gilardi et al. 2008), Botrytis cinerea (Elmer and Reglinski 2006), Alternaria solani (Abbasi and Weselowski 2014), and Phytophthora infestans (Olanya and Larkin 2006), and one bacterial pathogen, Xanthomanas spp. (Abbasi and Weselowski 2015). Another strain (B. subtilis BD170) has been used in the control of fire blight caused by Erwinia amylovora in apple orchards (Broggini et al. 2005). Species of Bacillus are known to produce diverse antimicrobial compounds such as fengycins, iturins, and surfactins, which have antagonistic activities against a wide range of plant pathogens, including bacteria, fungi, and oomycetes (Ongena and Jacques 2008). Although B. thuringiensis products are the most widely used microbial pesticides to control insect pests (Chattopadhyay et al. 2004), several other Bacillus species such as B. amyloliquefaciens, B. licheniformis, B. pumilus, and B. subtilis have been developed as biopesticide products especially for the control of fungal diseases. Species of Bacillus have the capacity to produce spores and they are relatively easy to grow, formulate, and store (Fendrihan et al. 2016; Piggot and Hilbert 2004).

There are five basic mechanisms of antagonism postulated for the effectiveness of biological agents, including direct parasitism, production of extracellular antibiotics or other substances, competition on the host, and stimulation of host defenses for biological agents (Blakeman and Brodie 1977). In our study, we can only speculate that the B. subtilis QST 713 strain might have inhibited P. pachyrhizi spore germination and development through the production of antibiotics or other inhibitory substances and/or by stimulation of host defenses. Further research in this area is needed to determine exactly how this strain reduced $P$. pachyrhizi sporulation.

The acibenzolar-S-methyl and harpin treatments reduced $P$. pachyrhizi sporulation similar to B. subtilis QST 713 at some application times and were generally better at reducing $P$. pachyrhizi 
sporulation than the other biopesticide products. The compounds acibenzolar-S-methyl and harpin protein are known to induce SAR against some rust pathogens. For instance, acibenzolar-S-methyl induced resistance in soybean, and this resulted in a longer latent period and reduction in P. pachyrhizi infection (Cruz et al. 2014). This compound was also reported to induce resistance to bacterial spot in bell pepper (Romero et al. 2001), providing 99\% control of Pseudomonas syringae pv. tabaci, 91\% control of Cercospora nicotianae, and $89 \%$ control of A. alternata (Cole 1999). Similarly, harpin protein induced resistance that resulted in rust reduction of up to $87 \%$ in winter jujube (Li et al. 2012) and blue mold reduction (de Capdeville et al. 2003). In addition, treating Chinese cabbage roots with harpin significantly decreased soft rot severity (Sun et al. 2010), whereas postharvest application of harpin on fruits


Fig. 1. Percent rust reduction on detached leaves for soybean cultivars Williams 82 and Asgrow 2242 after applying or not applying selected biopesticides 8 days before (8-B) to 8 days after (8-A) Phakopsora pachyrhizi inoculation. Percent rust reduction was calculated as follows: [100 - (number of sporulating uredinia per number of sporulating uredinia from the inoculated-nontreated treatment) $\times 100]$. The vertical bar represents the least significant difference value at $\alpha=0.05$ for all treatments. Control indicates inoculated control 
of Hami melons reduced pink rot lesions caused by Trichothecium roseum (Yang et al. 2005).

Neem oil and Trichoderma harzianum T-22 treatments reduced sporulation the most when applied 1 day before or after or on the day of inoculation and ranged from 67 to $88 \%$ reductions in both the detached-leaf assays and greenhouse evaluations. Neem oil was shown to inhibit urediniospore germination by $100 \%$ but had only moderate activity in the greenhouse experiment, reducing rust infection by $47 \%$ (Medice et al. 2007). Neem products were moderately

Table 3. Two-way analysis of variance using transformed percent soybean rust reduction from the greenhouse experiment for treatments (biopesticides), application times, trial, block, and interaction between biopesticides and application times ${ }^{\mathrm{x}}$

\begin{tabular}{lrrc}
\hline Source of variation & $\boldsymbol{d} \boldsymbol{f}$ & MS & $\boldsymbol{F}$ ratio $^{\mathbf{y}}$ \\
\hline Treatments & 5 & 6.23 & $620.39^{*}$ \\
Application times & 6 & 1.38 & $136.98^{*}$ \\
Treatments $\times$ application times & 30 & 0.11 & $10.92^{*}$ \\
Trial & 1 & 0.02 & 2.09 (ns) \\
Block & 2 & 0.01 & 0.26 (ns)
\end{tabular}

${ }^{x}$ Percent rust reduction was calculated as follows: [100 - (number of sporulating uredinia per number of sporulating uredinia from the inoculated-nontreated treatment) $\times 100] . d f=$ degrees of freedom, MS = mean squares, and $\mathrm{ns}=$ not significant.

y Asterisks indicate that significant differences were found at $P<0.001$.

${ }^{\mathrm{z}}$ Treatments included five biopesticides and the inoculated control without a biopesticide treatment. effective in controlling powdery mildew (Li et al. 2009) and they significantly retarded several growth parameters of the pathogen Erysiphe pisi (powdery mildew) on peas (Singh and Prithviraj 1997). Trichoderma harzianum T-22 is commonly used species for biological control, although there are several species in this genus reported as antagonists to other fungi (Maketon et al. 2008; Verma et al. 2007) and nematodes (Spiegel and Chet 1998). However, the ineffectiveness of Trichoderma species in controlling the bean rust fungus caused by $U$. appendiculatus on leaf disks was also reported (Burmeister and Hau 2009). Trichoderma species need ideal moisture and nutrient conditions and these conditions often occur in soil and associated roots, where they have been used in the control of soilborne pathogens (Hjeljord and Tronsmo 1998). In contrast, on leaf disks, lack of ideal conditions may hinder their growth to colonize leaf tissues, resulting in a lack of efficacy against foliar pathogens as we observed in the our study.

The biopesticide activity in our study differed from our report on testing synthetic fungicides before and after $P$. pachyrhizi inoculation

Table 4. Pearson correlation coefficients from mean transformed percent disease control values to assess the relationship between detached-leaf and greenhouse experiments of experiments using biopesticides to reduce the sporulation of the soybean rust fungus Phakopsora pachyrhizi ${ }^{\mathrm{z}}$

\begin{tabular}{lcc}
\hline Variable & GCW & GCA \\
\hline Growth chamber, Williams 82 (GCW) & - & \\
Growth chamber, Asgrow 2242 (GCA) & $0.94^{*}$ & - \\
Greenhouse, Williams 82 (GHW) & $0.95^{*}$ & $0.90^{*}$ \\
\hline
\end{tabular}

${ }^{\mathrm{z}}$ Dashes indicate no data. Asterisks indicate significant at $P<0.001$.

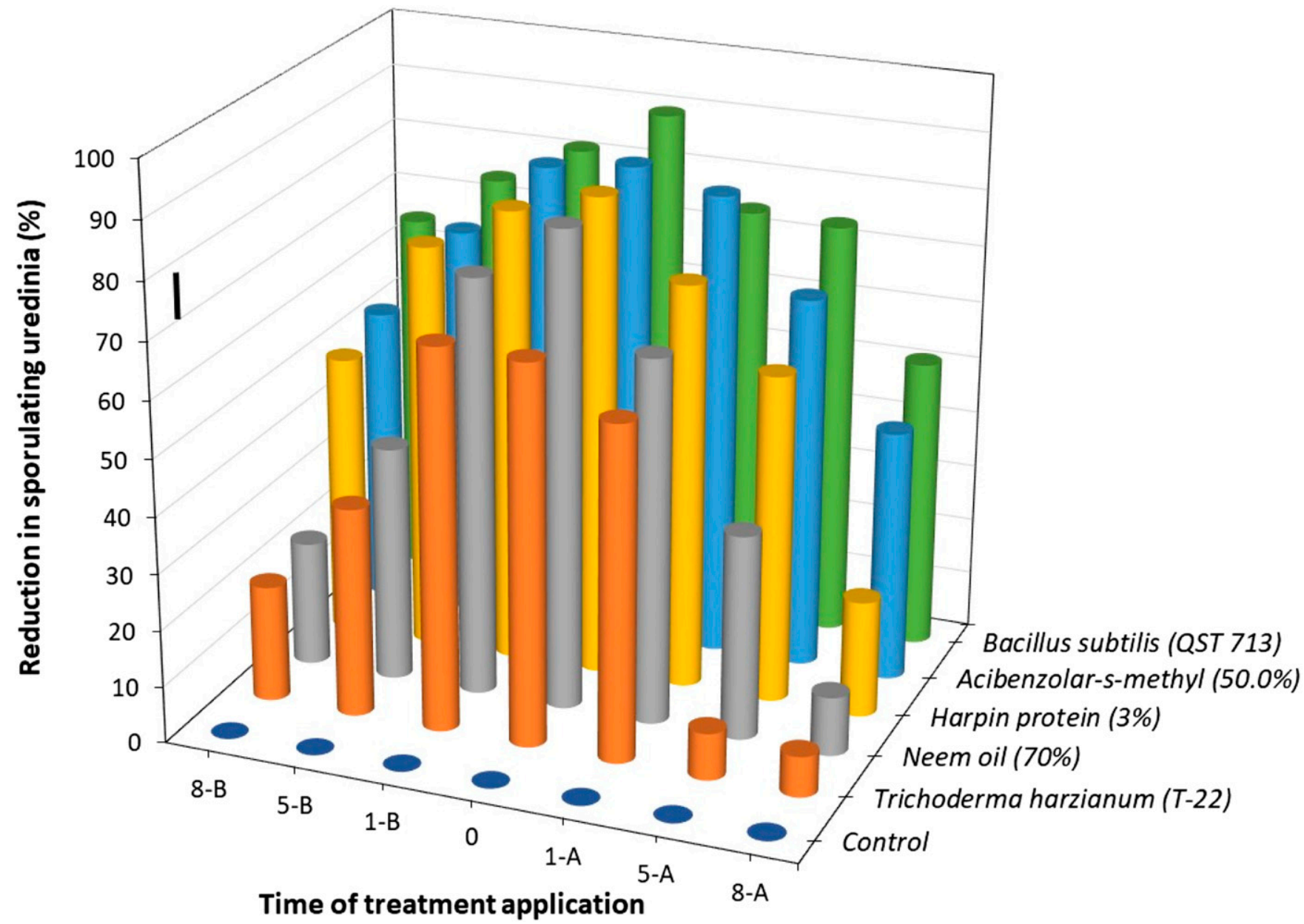

Fig. 2. Percent rust reduction on leaves of whole plants for soybean cultivar Williams 82 after applying or not applying selected biopesticides 8 days before (8-B) to 8 days after (8-A) Phakopsora pachyrhizi inoculation in the growth chamber. Percent rust reduction was calculated as follows: [ 100 - (number of sporulating uredinia per number of sporulating uredinia from the inoculated-nontreated treatment) $\times 100$ ]. The vertical bar represents the least significant difference value at $\alpha=0.05$ for all treatments. Control indicates inoculated control. 
(Twizeyimana and Hartman 2017). For instance, all synthetic fungicide treatments reduced rust infection by $100 \%$ when applied 2 days before and $3 \mathrm{~h}$ after inoculation in detached-leaf experiments for Williams 82 and Asgrow 2242, and percent rust reduction values ranged from 98 to $100 \%$ on Williams 82 plants in a greenhouse experiment (Twizeyimana and Hartman 2017). In the current study on biopesticides, percent rust reduction values for all biopesticide treatments applied 1 day before and $3 \mathrm{~h}$ after inoculation ranged from 74 to $96 \%$ in the detached-leaf experiments and 67 to $90 \%$ in the greenhouse experiments. Similarly, synthetic fungicides applied 8 days before or after inoculation had percent rust reduction values that ranged from 5 to $97 \%$ for both cultivars in the detached-leaf experiments and from 8 to $83 \%$ on Williams 82 plants in a greenhouse experiment (Twizeyimana and Hartman 2017). Biopesticide treatments applied 8 days before or after inoculation in the current study had percent rust reduction values from 4 to $74 \%$ for both cultivars in the detached-leaf experiments and from 7 to $65 \%$ in the greenhouse experiments. Although the lower range of reduction in sporulation is similar, the upper range of reduction was different, with the synthetic fungicides in general providing more control.

Lower rust reduction observed on biopesticide in the current study or our previous study with synthetic fungicides (Twizeyimana and Hartman 2017) applied 8 days before inoculation may have been due to the loss of biopesticide or fungicide activity deposited on the leaf surface over time. When a biopesticide or fungicide is applied to leaf surfaces, different factors influence their persistence, including structural stability, the metabolic activity of the plant, temperature regime, and the amount of precipitation, wind, and radiation, all of which can contribute to biopesticide degradation over time (Edwards 1975).

Control of SBR, especially in commercial fields where the disease is endemic, relies heavily on the use of synthetic fungicides (Godoy 2012; Sikora et al. 2014). The intensive use of these synthetic fungicides to control this disease has resulted in new fungal populations that are insensitive to commonly used fungicides (Godoy 2012; Klosowski et al. 2015; Schmitz et al. 2014; Twizeyimana and Hartman 2017). The integration of biopesticides that had high percent rust reduction values in our study (B. subtilis QST 713, acibenzolar-Smethyl, and harpin) with IPM programs may mitigate the problem of fungicide resistance. For instance, when B. subtilis isolate QST 713 and fungicides sulfur (Microthiol 80DF), myclobutanil (Rally $40 \mathrm{~W}$ ), and trifloxystrobin (Flint 50WG) were used to control powdery mildew in lettuce, there were no significant differences between a combination of low rates of serenade $(2.24 \mathrm{~kg} / \mathrm{ha})$ plus low rates of sulfur $(4.48 \mathrm{~kg} / \mathrm{ha})$ and full rates of sulfur $(8.96 \mathrm{~kg} / \mathrm{ha})$ or myclobutanil (70.6 g active ingredient [a.i.]/ha) (Matheron and Porchas 2000). In addition, these authors found no significant differences between treatments consisting of alternation of serenade $(4.48$ $\mathrm{kg} / \mathrm{ha})$ with sulfur $(8.96 \mathrm{~kg} / \mathrm{ha})$ or myclobutanil (70.6 g a.i./ha) and nonaltered treatments of sulfur $(8.96 \mathrm{~kg} / \mathrm{ha})$ or myclobutanil (70.6 g a.i./ha) (Matheron and Porchas 2000).

Combining potential biopesticides with resistant cultivars, good cultural controls, and reduced rates of pesticides in SBR management programs may be key to reducing not only the "risk of resistance" in $P$. pachyrhizi populations to synthetic fungicides but also the environmental pollution caused by synthetic pesticide residues.

\section{Literature Cited}

Abbasi, P. A., and Weselowski, B. 2014. Influence of foliar sprays of Bacillus subtilis QST 713 on development of early blight disease and yield of field tomatoes in Ontario. Can. J. Plant Pathol. 36:170-178.

Abbasi, P. A., and Weselowski, B. 2015. Efficacy of Bacillus subtilis QST 713 formulations, copper hydroxide, and their tank mixes on bacterial spot of tomato. Crop Prot. 74:70-76.

Bettiol, W., and Várzea, V. M. P. 1992. Controle biológico da ferrugem (Hemileia vastatrix) do cafeeiro com Bacillus subtilis em condições controladas. Fitopatol. Bras. 17:91-95.

Blakeman, J. P., and Brodie, I. D. S. 1977. Competition for nutrients between epiphytic micro-organisms and germination of spores of plant pathogens on beetroot leaves. Physiol. Plant Pathol. 10:29-42.

Broggini, G. A. L., Duffy, B., Holliger, E., Schärer, H.-J., Gessler, C., and Patocchi, A. 2005. Detection of the fire blight biocontrol agent Bacillus subtilis BD170 (Biopro $\left.{ }^{\circledR}\right)$ in a Swiss apple orchard. Eur. J. Plant Pathol. 111:93-100.
Burmeister, L., and Hau, B. 2009. Control of the bean rust fungus Uromyces appendiculatus by means of Trichoderma harzianum: Leaf disc assays on the antibiotic effect of spore suspensions and culture filtrates. BioControl 54: 575-585.

Chattopadhyay, A., Bhatnagar, N. B., and Bhatnagar, R. 2004. Bacterial insecticidal toxins. Crit. Rev. Microbiol. 30:33-54.

Cole, D. L. 1999. The efficacy of acibenzolar-S-methyl, an inducer of systemic acquired resistance, against bacterial and fungal diseases of tobacco. Crop Prot. 18:267-273

Cook, R. T. A. 2001. First report in England of changes in the susceptibility of Puccinia horiana, the cause of chrysanthemum white rust, to triazole and strobilurim fungicides. Plant Pathol. 50:792.

Copping, L. G., and Menn, J. J. 2000. Biopesticides: A review of their action, applications and efficacy. Pest Manag. Sci. 56:651-676.

Cruz, M. F. A., Rodrigues, F. Á., Diniz, A. P. C., Alves Moreira, M., and Barros, E. G. 2014. Soybean resistance to Phakopsora pachyrhizi as affected by acibenzolar-S-methyl, jasmonic acid and silicon. J. Phytopathol. 162:133-136.

de Capdeville, G., Beer, S. V., Watkins, C. B., Wilson, C. L., Tedeschi, L. O., and Aist, J. R. 2003. Pre- and post-harvest harpin treatments of apples induce resistance to blue mold. Plant Dis. 87:39-44.

Dorighello, D. V., Bettiol, W., Maia, N. B., and de Campos, R. M. V. B. 2015 Controlling Asian soybean rust SBR (Phakopsora pachyrhizi) with Bacillus spp. and coffee oil. Crop Prot. 67:59-65.

Edwards, C. A. 1975. Factors that affect the persistence of pesticides in plants and soils. Pure Appl. Chem. 42:39-56.

Elmer, P. A. G., and Reglinski, T. 2006. Biosuppression of Botrytis cinerea in grapes. Plant Pathol. 55:155-177.

Fendrihan, S., Constantinescu, F., Sicuia, O. A., and Dinu, S. 2016. Beneficial Bacillus strains improve plant resistance to phytopathogens: A review. Int. J. Environ. Agric. Biotechnol. 1:137-142.

Gilardi, G., Manker, D. C., Garibaldi, A., and Gullino, M. L. 2008. Efficacy of the biocontrol agents Bacillus subtilis and Ampelomyces quisqualis applied in combination with fungicides against powdery mildew of zucchini. J. Plant Dis. Prot. 115:208-213.

Godoy, C. V. 2012. Risk and management of fungicide resistance in the Asian soybean rust fungus. Pages 87-95 in: Fungicide Resistance in Crop Protection: Risk and Management. T. S. Thind, ed. CABI Publishing, Wallingford, UK.

Gorlach, J., Volrath, S., Knauf-Beiter, G., Hengy, G., Beckhove, U., Kogel, K.-H., Oostendorp, M., Staub, T., Ward, E., Kessmann, H., and Ryals, J. 1996. Benzathiadiazole, a novel class of inducers of systemic acquired resistance, activates gene expression and disease resistance in wheat. Plant Cell 8:629-643.

Hartman, G. L., Miles, M. R., and Frederick, R. D. 2005. Breeding for resistance to soybean rust. Plant Dis. 89:664-666.

Hartman, G. L., Pawlowski, M. L., Chang, H. X., and Hill, C. B. 2016. Successful technologies and approaches used to develop and manage resistance against crop diseases and pests. Pages 43-66 in: Emerging Technologies for Promoting Food Security. C. Madramootoo, ed. Woodhead Publishing, Cambridge, UK.

Hartman, G. L., Wang, T. C., and Tschanz, A. T. 1991. Soybean rust development and the quantitative relationship between rust severity and soybean yield. Plant Dis. 75:596-600.

Hjeljord, L., and Tronsmo, A. 1998. Trichoderma and Gliocladium in biological control: An overview. Pages 131-151 in: Trichoderma and Gliocladium. Harman, G. E., and Kubicek, C. P., eds. Vol. 2. Taylor \& Francis, London, UK.

Klosowski, A. C., May De Mio, L. L., Miessner, S., Rodrigues, R., and Stammler, G. 2015. Detection of the F129L mutation in the cytochrome b gene in Phakopsora pachyrhizi. Pest Manag. Sci. 72:1211-1215.

Leahy, J., Mendelsohn, M., Kough, J., Jones, R., and Berckes, N. 2014. Biopesticide oversight and registration at the Environmental Protection Agency. Pages 3-18. In: Biopesticides: State of the Art and Future Opportunities. A. D. Gross, J. R. Coats, S. O. Duke, and J. N. Seiber, eds. American Chemical Society, Washington, DC.

Li, M., Yu, M. L., Zhang, Z. Q., Wu, Y. C., Liu, Z. G., and Zhao, C. H. 2012 Harpin induces rust disease (Phakopsora zizyphi-vulgaris) resistance on winter jujube (Ziziphus jujube Mill. cv. Dongzao). Biol. Agric. Hortic. 28: 177-184.

Li, Y., Mmbaga, M. T., Windham, A. S., Windham, M. T., and Trigiano, R. N 2009. Powdery mildew of dogwoods: Current status and future prospects. Plant Dis. 93:1084-1092.

Maketon, M., Apisitsantikul, J., and Siriraweekul, C. 2008. Greenhouse evaluation of Bacillus subtilis AP-01 and Trichoderma harzianum AP-001 in controlling tobacco diseases. Braz. J. Microbiol. 39:296-300.

Matheron, M. E., and Porchas, M. 2000. Evaluation of fungicide performance for control of powdery mildew on lettuce in 2000. Pages XX-XX in: Vegetable: College of Agriculture Report 2000. Online publication no. AZ1177. University of Arizona College of Agriculture, Tucson.

Medice, R., Alves, E., Assis, R. D., Magno, R. G., Jr., and Lopes, E. A. G. L. 2007 Essential oils used in the control of Asian soybean rust Phakopsora pachyrhizi Syd. \& P. Syd. Cienc. Agrotec. 31:83-90.

Mueller, T. A., Miles, M. R., Morel, W., Marois, J. J., Wright, D. L., Kemerait, R C., Levy, C., and Hartman, G. L. 2009. Effect of fungicide and timing of application on soybean rust severity and yield. Plant Dis. 93:243-248. 
Obradovic, A., Jones, J. B., Momol, M. T., Olson, S. M., Jackson, L. E., Balogh, B., Guven, K., and Iriarte, F. B. 2005. Integration of biological control agents and systemic acquired resistance inducers against bacterial spot on tomato. Plant Dis. 89:712-716.

Olanya, O. M., and Larkin, R. P. 2006. Efficacy of essential oils and biopesticides on Phytophthora infestans suppression in laboratory and growth chamber studies. Biocontrol Sci. Technol. 16:901-917.

Ongena, M., and Jacques, P. 2008. Bacillus lipopeptides: Versatile weapons for plant disease biocontrol. Trends Microbiol. 16:115-125.

Piggot, P. J., and Hilbert, D. W. 2004. Sporulation of Bacillus subtilis. Curr. Opin. Microbiol. 7:579-586.

Romero, A. M., Kousik, C. S., and Ritchie, D. F. 2001. Resistance to bacterial spot in bell pepper induced by acibenzolar-S-methyl. Plant Dis. 85:189-194.

Saksirirat, W., and Hoppe, H. H. 1990. Light- and scanning electron microscopic studies on the development of the mycoparasite Verticillium psalliotae Treschow on uredospores of the soybean rust (Phakopsora pachyrhizi Syd.). J. Phytopathol. 128:340-344.

Saksirirat, W., and Hoppe, H. H. 1991a. Degradation of uredospores of the soybean rust fungus (Phakopsora pachyrhizi Syd.) by cell-free culture filtrates of the mycoparasite Verticillium psalliotae Treschow. J. Phytopathol. 132:33-45

Saksirirat, W., and Hoppe, H. H. 1991b. Secretion of extracellular enzymes by Verticillium psalliotae Treschow and Verticillium lecanii (Zimm.) Viegas during growth on uredospores of the soybean rust fungus (Phakopsora pachyrhizi Syd.) in liquid cultures. J. Phytopathol. 131:161-173.

Sangit, K., and Jha, D. K. 2002. Trichothecium roseum: A potential agent for the biological control of soybean rust (Phakopsora pachyrhizi Syd.). Indian Phytopathol. 55:232-234.

Schmitz, H. K., Medeiros, C.-A., Craig, I. R., and Stammlerd, G. 2014. Sensitivity of Phakopsora pachyrhizi towards quinone-outside-inhibitors and demethylation inhibitors, and corresponding resistance mechanisms. Pest Manag. Sci. 70: 378-388.

Sikora, E. J., Allen, T. W., Wise, K. A., Bergstrom, G., Bradley, C. A., Bond, J., Brown-Rytlewski, D., Chilvers, M., Damicone, J., DeWolf, E., Dorrance, A., Dufault, N., Esker, P., Faske, T. R., Giesler, L., Goldberg, N., Golod, J., Gomez, I. R. G., Grau, C., Grybauskas, A., Franc, G., Hammerschmidt, R., Hartman, G. L., Henn, A., Hershman, D., Hollier, C., Isakeit, T., Isard, S., Jacobson, B., Jardine, D., Kemerait, B., Koenning, S., Langham, M., Malvick, D., Markell, S., Marois, J. J., Monfort, S., Mueller, D., Mueller, J., Mulroony, R., Newman, M., Osborne, L., Padgett, G. B., Ruden, B. E., Rupe, J., Schneider, R., Schwartz, H., Shaner, G., Singh, S., Stromberg, E., Sweets, L., Tenuta, A., Vaiciunas, S., Yang, X. B., Young-Kelly, H., and Zidek, J. 2014. A coordinated effort to manage soybean rust in North
America: A success story in soybean disease monitoring. Plant Dis. 98: 864-875.

Singh, U. P., and Prithviraj, B. 1997. Neemazal, a product of neem (Azadirachta indica) induces resistance in pea (Pisum sativum) against Erysiphe pisi. Physiol. Mol. Plant Pathol. 51:181-194.

Spiegel, Y., and Chet, I. 1998. Evaluation of Trichoderma spp. as a biocontrol agent against soil-borne fungi and plant-parasitic nematodes in Israel. Integr. Pest Manage. Rev. 3:169-175.

Sun, L., Wang, X., Qu, S., Liu, H., Jia, Z., and Dong, H. 2010. HrpNEa induces Chinese cabbage resistance to bacterial soft rot by inhibiting the bacterial attachment to root surfaces. Plant Dis. 94:1441-1447.

Twizeyimana, M., and Hartman, G. L. 2010. Culturing Phakopsora pachyrhizi on detached leaves and urediniospore survival at different temperatures and relative humidities. Plant Dis. 94:1453-1460.

Twizeyimana, M., and Hartman, G. L. 2017. Sensitivity of Phakopsora pachyrhizi isolates to fungicides and reduction of fungal infection based on fungicide and timing of application. Plant Dis. 101:121-128.

Twizeyimana, M., Ojiambo, P. S., Hartman, G. L., and Bandyopadhyay, R. 2011 Dynamics of soybean rust epidemics in sequential plantings of soybean cultivars in Nigeria. Plant Dis. 95:43-50.

Twizeyimana, M., Ojiambo, P. S., Ikotun, T., Ladipo, J. L., Hartman, G. L., and Bandyopadhyay, R. 2008. Evaluation of soybean germplasm for resistance to soybean rust (Phakopsora pachyrhizi) in Nigeria. Plant Dis. 92:947-952.

Verma, M., Brar, S. K., Tyagi, R. D., Surampalli, R. Y., and Valero, J. R. 2007 Antagonistic fungi, Trichoderma spp.: Panoply of biological control. Biochem. Eng. J. 37:1-20.

Walters, D., Walsh, D., Newton, A., and Lyon, G. 2005. Induced resistance for plant disease control: Maximizing the efficacy of resistance elicitors. Phytopathology 95:1368-1373.

Ward, N. A., Robertson, C. L., Chanda, A. K., and Schneider, R. W. 2012. Effects of Simplicillium lanosoniveum on Phakopsora pachyrhizi, the soybean rust pathogen, and its use as a biological control agent. Phytopathology 102 749-760.

Wei, Z. M., Laby, R. J., Zumoff, C. H., Bauer, D. W., He, S. Y., Collmer, A., and Beer, S. V. 1992. Harpin, elicitor of the hypersensitive response produced by the plant pathogen Erwinia amylovora. Science 257:85-88.

Yang, B., Shiping, T., Jie, Z., and Yonghong, G. 2005. Harpin induces local and systemic resistance against Trichothecium roseum in harvested Hami melons. Postharvest Biol. Technol. 38:183-187.

Yorinori, J. T., Paiva, W., Frederick, R. D., Castamilan, L., Bertagnolli, P., Hartman, G. L., Godoy, C., and Nunes, J. J. 2005. Epidemics of soybean rust (Phakopsora pachyrhizi) in Brazil and Paraguay from 2001 to 2003. Plant Dis. 89:675-677. 